\title{
PERAN MODAL SOSIAL FILSAFAT TRI TANGTU SILIH DALAM PEMBERDAYAAN EKONOMI MASYARAKAT DI DESA ALAMENDAH RANCABALI BANDUNG
}

\author{
Siswanto Masruri \\ siswantomasruri@gmail.com \\ Dosen UIN Sunan Kalijaga \\ R Lukman Fauroni \\ elfauroni@yaboo.co.id \\ Dosen IAIN Surakarta
}

\begin{abstract}
The economic empowerment of communities often tend to focus on the aspect of method and program, which is mostly imported and western-minded. Social capital may be opimized to make sure that the economic empowerment achieving its goals. In some conditon, the social capital philosophy of tri tangtu silib asih silih asah and silih asub plays a significant role in ensuring the success of a community economic empowerment. This paper is a study of social system of community economic empowerment aiming on understanding the background condition of the economic empowerment of a village community with particular case of the village farmer group.
\end{abstract}

Keywords: The Social Capital Role, Philosophy of Tri Tangtu Silih, Economic Empowerment.

\begin{abstract}
Abstrak
Pemberdayaan ekonomi masyarakat sering kali lebih fokus pada aspek metode dan program yang biasanya datang dari luar babkan bernuansaBarat. Modal sosial dapat dioptimalisasikan untuk keberhasilan pemberdayaan ekonomi masyarakat. Dalam berbagai kondisi, modal sosial filsafat tri tangtu silih asib silih asab dan silih asubberperan signifikan terbadap keberhasilan pemberdayaan ekonomi suatu masyarakat. Tulisan ini adalah kajian tentang sistem sosial pemberdayaan ekonomi, sebagai upaya memahami kondisi yang melatarbelakangi keberhasilan pemberdayaan ekonomi masyarakat melalui kelompok tani desa.
\end{abstract}

Kata Kunci: Peran Modal Sosial, Filsafat Tri Tangtu Silih, Pemberdayaan Ekonomi 


\section{Pendahuluan}

Pemberdayaan ekonomi masyarakat dapat diberlakukan melalui berbagai pendekatan dan metode.Namun, inisiatif dan pilihan atas pendekatan dan metodenyasering kali datang dari luar, bahkan diimpor dari Barat. Ada pendekatan struktural dan fungsional. Pendekatan struktural memosisikan peran aktif dari pihak eksternal sebagai inisiator. Bahkan cenderung mencontoh dari negara-negara Barat. Akibatnya, sering kali tidak sesuai dengan kondisi kebutuhan masyarakat sasaran atau dampingan.Sementara pendekatan fungsional menitikberatkan pendekatan kultural yang berupaya secara bersama-sama memunculkan dan mengembangkan pergerakan dari dalam. Pemberdayaan ekonomi dapat dilakukan melaluiperluasan akses permodalan, bimbingan teknis dan pendampingan pengembangan usaha kecil, manajemen pemasaran, keuangan, investasi dan lain-lain.

Sebesar upaya pihak eksternal dalam pemberdayaan ekonomi masyarakat, kerap kali tidak berbanding lurus dengan tingkat keberhasilannya. Ketika peran aktif bahkan jenis program diadopsi dari negara-negara Barat, maka, pemberdayaan masyarakat sering menghadapi kendala bahkan mengalami jalan buntu. Dan program pemberdayaan hanya dipahami sebagai project, yang harus selesai secara proses dan ada laporannya.

Berdasar hal itu, pemberdayaan masyarakat, mempersyaratkan muncul dan berkembangnya inisiatif, kemauan keras dan pergerakan dari pihak internal.Pola pemberdayaan inilah yang disebut pemberdayaan dengan pendekatan fungsional dengan mengedepankan aspek kultural. Pendekatan fungsional memberi peluang bagi optimalisasi sistem nilai budaya, kearifan lokal bagi keberhasilan pemberdayaan itu.

Sistem nilai budaya, norma, atau kearifan lokal merupakan modal sosial. Menurut World Bank, modal sosial adalah:..." $a$ society includes the institutions, the relationships, the attitudes and values that govern interactions among people and contribute to Economic and social Development. (World bank, 1998). Modal sosial dapat diterapkan untuk berbagai kebutuhan, termasuk dalam pemberdayaan masyarakat. World bank memberi perhatian yang 
tinggi dengan mengkaji peranan dan implementasi modal sosial guna pengentasan kemiskinan di negara-negara berkembanga.

Dalam konteks pemberdayaan ekonomi, pengembangan modal sosial didasarkan pada asumsi-asumsi sebagai berikut:Pertama, modal sosial berada dalam seluruh keterkaitan ekonomi, sosial dan politik serta hubungan sosial, yang mempengaruhi bagaimana pasar dan negara bekerja. Kedua, dengan modal sosial, hubungan yang stabil antar aktor, dapat mendorong efektivitas dan efisiensi baik perilaku kolektif maupun individual. Ketiga, modal sosial dalam suatu masyarakat dapat diperkuat, namun membutuhkan dukungan sumber daya yang lain. Keempat, agar tercipta hubungan sosial dan kelembagaan yang baik maka anggota masyarakat harus mendukungnya. (Syahyuti, 2008).

Menurut Schiff(2000), era perdanganan bebas dan migrasi bebas sekalipun, sangat membutuhkan modal sosial. Demikian pula menurut Brata(2004), modal sosial merupakan isu menarik pada era modern. Modal sosial memiliki dampak yang signifikan terhadap proses-proses pembangunan. Modal sosial akan bernilai ekonomis, ketika dapat membantu individu atau kelompok dalam mengakses sumber-sumber ekonomi, keuangan, informasi, pekerjaan, merintis usaha dan meminimalkan biaya ekonomi.

Di desa Alamendah khususnya dan masyarakat Sunda umumnya memiliki modal sosial yang berujud adagium silib silih asih, silih asah dan silih asuh. Adagium ini bermakna dan dirasakan dalam tatanan kehidupan sosial budaya, yang menunjukkan kehidupan sosial masyarakat yang baik, saling menyayangi-mengayomi dan jauh dari pertikaian. Di desa Alamendah, adagium ini ternyata jauh melampaui tatanan sosial kemasyarakatan, melainkan dapat menjangkau tananan ekonomi yaitu pemberdayaan ekonomi melalui pembentukan dan pengembangan kelompok-kelompok tani secara berkesinambungan. Tulisan ini secara khusus mengkaji modal sosial silih asih, silih asah dan silih asubyang berakar dari filsafat kasundaan tri tangtu.

Berdasar permasalahan di atas, tulisan ini mengkaji, pertama, sistem nilai apa yang menjadi episentrum keberhasilan pemberdayaan ekonomi kelompok tani desa Alamendah. Kedua, 
mengapa kelompok tani dapat menggapai keberhasilan. Ketiga, bagaimana sistem jaringan yang diberlakukan sehingga mendukung keberhasilan pemberdayaan ekonomi masyarakat.

\section{Ajaran Agama, Sistem Nilai dan Pemberdayaan Masyarakat}

Penelitian tentang sistem nilai bukanlah penelitian yang asing. Namun penelitian sistem nilai yang terkait dengan pemberdayaan ekonomi masyarakat hemat penulis, termasuk masih jarang.Sistem nilai ajaran agama, dipahami Lance Castle (1982) berpengaruh pada tingkah laku ekonomi, kewiraswastaan, perdagangan dan pabrik meskipun tidak secara tegas.Berbeda dengan Castle, Irwan Abdullah (1994), menyimpulkan, ketaatan pada sistem nilai ajaran agama, sangat terkait dengan keberhasilan pebisnis muslim dan dukungan faktor lain seperti struktur sosial politik masyarakat. Agama memiliki peran penting dalam proses pembaharuan pemikiran yang mengarahkan perilaku ekonomi pebisnis muslim dan mempengaruhi cara penduduk menerima bisnis sebagai bagian dari kehidupan mereka.

Sistem nilai ajaran agama membentuk dasar sosial budaya yang memungkinkan kegiatan ekonomi dapat berlangsung. Namun perkembangan bisnis selanjutnya ditentukan oleh struktur politik lokal dan iklim politik yang ada. Kesuksesan pebisnis di perkotaan ditopang oleh meningkatnya kesejahteraan kaum tani di wilayahnya.

Keterkaitan antara kehidupan masyarakat Sunda dengan nilai ajaran agama ditegaskan oleh laporan keuskupan Bogor. Kehidupan orang Sunda sangat kental dengan sistem nilai ajaran agama.Masyarakat Sunda sering diidentikkan dengan Islam;memiliki ciri menjunjung tinggi persahabatan dan persaudaraan. Ciri-ciri itu terlihat dalam guguritan pupuh pucang; (MGR Michael C., 2011).

Hampelas raraga jati

Palataran babalean

Iklas raga jeung pati

Ngabelaan kasaean

(Menghaluskan (dengan amplas) rangka dari kayu jati)

(Pelataran bale-bale)

(Rela mengorbankan jiwa dan raga) 
(demi membela kebaikan)

Utama jalma kudu rea batur

Keur silib tulungan

Silih titipkeun nya diri

Budi akal landaran ti pada jalma

(Orang yang baik adalah yang punya banyak teman)

(untuk saling tolong menolong)

(saling menitipkan diri)

(Akal budi berasal dari sesama manusia)

Guguritan itu memperlihatkan kondisi sosial budaya masyarakat Sunda yang kuat antara budaya dan sistem nilai ajaran agamanya, mengindikasikan filsafat hidup manusia Sunda. Kebudayaan Sunda serta kearifan dan spiritualitasnya, merupakan implementasi kearifan Ilahi yang berwajah genuine dan lokal (Agus A. Syae'i, 2010; 4).

Menurut Ginanjar Kurnia (2004), diterimanya Islam secara baik di tatar Sunda, karena keduanya mempunyai persamaan paradigmatik yang berciri Platonik. Islam memandang dunia sebagai ungkapan azas-azas mutlak yang terekam dalam wahyu Allah SWT. Sedangkan kebudayaan Sunda mengimplementasikan nilai-nilai mutlak dalam adat-istiadat dan keseharian.Persamaan dan integrasi antara sistem nilai Islam dan Sunda, disimpulkan Haji Hasan Mustapa; urang Sunda mah geus Islam samemeh Islam (orang Sunda itu sudah Islam sebelum datangnya Islam). Atau dalam istilah Endang Saefudin Anshari, Sunda-Islam dan Islam-Sunda. Sistem nilai dan ajaranIslamdisosialisasikan melalui beragam matra kehidupan, seperti seni dan budaya, pewayangan (wayang golek), lagu-lagu, pepatah, pantun, bahkan banyolan-banyolan (humor).

Silih asih silih asah dan silih asub,merupakan salah satu adagium yang berasal dari filsafat kasundaan tri tangtu yang bermakna tiga ketentuan: saling mengasihi, saling belajar, saling mengayomi. Tiga silih itu menggambarkan arah bangunan kehidupan sosialmasyarakat Sunda. Seirama dengan tiga silih di antaranya, jeung sasama kudu kawas dulurpet ku hinis, ulab untung sorangan, kudu repeh rapih(hubungan dengan sesama harus seperti dengan saudara sekandung, tidak boleh untung sendiri, harus tenang dan 
teratur dan lain-lain. Contoh lain filsafat tri tangtu;mista maja utama, jika hasil perbuatan pertama kurang baik, lakukan kedua, maka yang ketiga akan berhasil. Tekad ucap lampah, keyakinan, perkataan dan perbuatan harus menyatu, yang dapat diposisikan sebagai impelentasi iman Islam dan ihsan.

Dalam khazanah Islam, filsafat tri tangtu tiga silib tampak mempunyai kaitan erat dengan ajaran ukhuwah. Ukhuwah bermakna bukan sekedar persaudaraan dalam pengertian yang sempit, melainkan suatu ikatan perekat sosial ekonomi yang erat dan berpengaruh signifikan terhadap pencapaian kemajuan masyarakat. Dalam kamus Al-Munawwir, ukhuwah berakar dari kata akhā-ukhuwatun, berarti menjadi saudara atau kawan. Al-akhāwiyyah, ukhuwwah, al-Ikhä'u, bermakna persaudaraan.Dalam $A$ Dictionary of Modern Writen ArabicHans Wehr, ukhuwah atau ikhwan bermakna: brother, fellowman, brethren atau member of an order religions barotherhood of the militan in character. Ukhuwah merupakan suatu ikatan bathin yang kuat, kokoh, yang terekpresi dalam sikap dan perilaku seseorang atau komunitas sehingga berkarakter jalinan kohesi sosial yang erat, saling percayamempercayai, memberi dan menerima, mengayomi, menanggung dan mengabdi untuk kemajuan bersama.

Dalam al-Qur'an, ukhuwah mempunyai landasan makna dan operasional yang sangat kuat. Di antara landasannya terdapat pada al-Hujurat (49): 10,

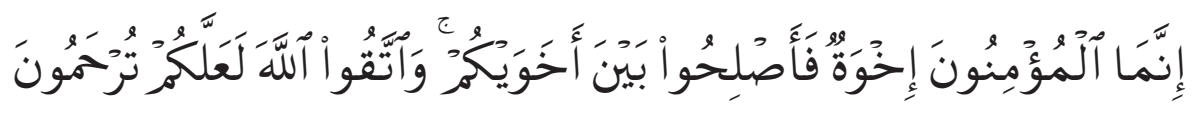

Ayat ini mengarahkan keharusan menyelesaikan perbedaan atau perselisihan di antara kaum muslimin dengan cara damai dan adil dengan landasan takwa kepada Allah, karena hubungan antara orang yang beriman adalah saudara.

Dalam surat Ali Imran (3): 103 dinyatakan pula,

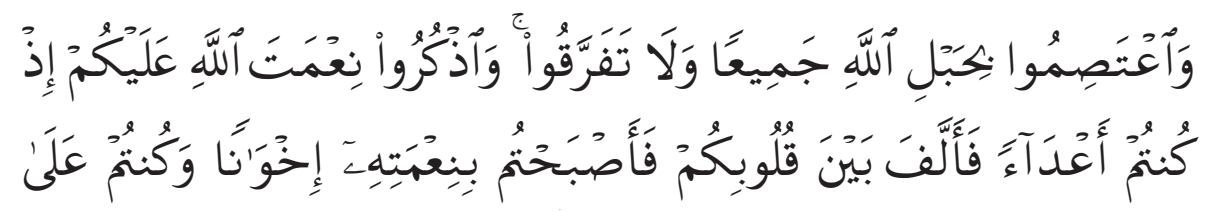




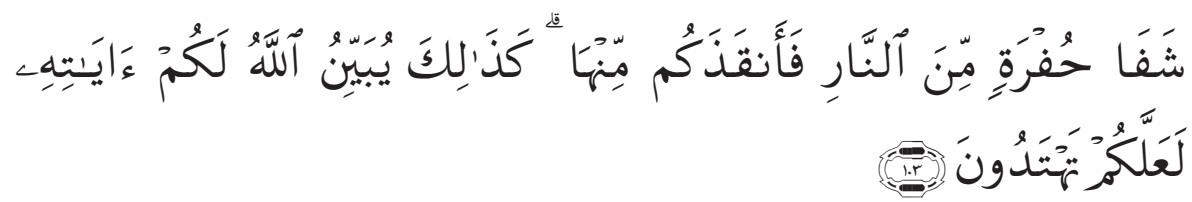

Pada ayat ini secara eksplisit dinyatakan keharusan berpegang teguh pada ajaran agama Allah dan tidak boleh bercerai-berai. Persaudaraan merupakan anugerah Allah yang tiada ternilai atas kaum muslimin. Landasan ukhuwah, diperkuat pula oleh sejumlah hadis Nabi. Dalam hadis yang diriwayatkan oleh Bukhari dan Muslim dari Abi Hamzah dinyatakan, "Seseorang belum beriman jika belum mencintai saudaranya seperti mencintai diri sendiri". Dari hadis ini, dapat diambil ajaran bagaimana Islam memosisikan persatuan, persaudaraan dan kasih sayang sebagai landasan penciptaan masyarakat yang harmonis.

Demikian pula, hadis riwayat Bukhari Muslim yang lain; "hubungan antar sesama orang yang beriman seperti hubungan antar bagian pada suatu bangunan yang kokoh, atau seperti hubungan tak terpisahkan antar anggota tubuh, sehingga jika satu bagian tubuh merasakan sakit, maka otomatis anggota tubuh yang lain merasakan sakit juga".

Kekuatan ajaran ukhuwah dibuktikan pula oleh catatan sejarah, keberhasilan pembangunan masyarakat Islam (negara) di Madinah melalui strategi Nabi mempersaudarakan kaum Muhajirin dan Anshor sesampainya di Yasrib. Model persaudaraan ini dinilai sebagai strategi yang jitu dalam membangun kekuatan masyarakat bahkan suatu negara.

Kekuatan ikatan al-anșāb atau hubungan darah pada masyarakat Arab yang sangat kuat dan kental, digantikan oleh Nabi dengan persaudaraan berdasar keimanan. Dari model persaudaraan inilah, masyarakat kota Madinah menjadi suatu masyarakat yang kokoh dan kuat sehingga sulit dicerai berai. Persaudaraan telah menjadi kekuatan fundamental, sebagai fondasi bangunan peradaban Islam yang menyebar ke berbagai belahan dunia.

Tahun 2004, Brata melakukan penelitian tentang modal sosial di Yogyakarta. Penelitian menyimpulkan, modal sosial berupa 
jaringan sekampung halaman telah membuka jalan untuk jariangan sosial yang ada da bermanfaat dalam memperoleh bantunan modal yang bersifat informal, yaitu ketika bantunan formal dari pemerintah sangat terbatas. Modal sosial yang mereka miliki telah menciptakan nilai ekonomi bagi dirinya.

Demikian pula penelitian Bastelaers (2000); anggota masyarakat yang paling miskin yang tidak memiliki akses terhadap fasilitas mikro-kredit, menjadikan jaringan-jaringan sosial sebagai elemen penting dalam pemenuhan aspek permodalan. Seirama Bastelaers, Kolopaking (2002) menyimpulkan, modal sosial berperan dari kegiatan awal dalam berbagai kegiatan pada tingkat komunitas, hingga usaha-usaha kecil dan gurem dari komunitas ke organisasi desa yang pada akhirnya menjadi unsur pengelolaan kolaborasi serta memelihara jejaring kolaborasi tersebut.

Dari paparan penelitian terdahulu, dapat digarisbawahi, modal sosial dapat berpengaruh terhadap pemberdayaan masyarakat. Keterkaitan antara modal sosial sistem nilai yang berakar dari kristalisasi sejarah dialog ajaran agama dan budaya atau kearifan lokal terhadap pemberdayaan ekonomi masyarakat menjadi pembeda kajian ini dari kajian-kajian sebelumnya.

\section{Metode Penelitian}

Tulisan ini merupakan hasil penelitian kualitatif yang mengeksplorasi secara menyeluruh fenomena yang khas. Kajian menelaah fenomena sosial, budaya dan keagamaan yang berlangsung secara wajar dan alamiah (Bogdan Robert C. Biklen Sari Knop, 1992). Desain ini dinilai tepat mengungkap fenomena khas, karena dapat mengeksplorasi hal ihwal fenomena unik, meliputi nilai, norma, kebiasaan, sikap mental hingga kultur suatu komunitas.

Data primer diambil dengan metode observasi terlibat selama satu bulan efektif. Wawancara mendalam dilakukandengan cara snow ball. Analisis data menggunakan analisis interaktif sebagaimana oleh Miles dan Huberman. Untuk mengeliminir error dan membuktikan data valid dilakukan prosedur verifikasi,pertama, memeriksa kerepresentatifan, yaitu menguji sejumlah temuan dengan teknik memilah kasus. Kedua,member check, konfirmasi 
hasil pengumpulan dan analisis data pada beberapa responden yang memiliki kapabilitas ilmiah.Ketiga,trianggulasi teori, yaitu membandingkan dan menguji suatu temuan dengan teori lain atau data yang lain (John W. Creswell, 1989).

\section{Filsafat Tri Tangtu Silib untuk Pemberdayaan Ekonomi}

\section{Profil Desa Alamendah}

Desa Alamendah, atau alam yang indahterbentuk tahun 1978 sebagai pemekaran dari desa Ciwidey. Ohan Burhanuddin adalah kepala desa pertama.Saat ini kepala desa dijabat oleh, tokoh masyarakat dari kampung Cilastari.Desa Alamendah mempunyai wilayah yang luas, dengan penduduk 7.721 jiwa, terdiri 9.375.1akilaki dan 8.324 perempuan, dengan jumlah Rukun Warga (RW) sebanyak 30, terdiri dari 112 Rukun Tetangga (RT). (Data base Desa, 2010). Desa ini merupakan desa terluas dan menjadi desa yang paling berpengaruh dalam kontribusi ekonomi, bahkan di kabupaten Bandung.

Luas lahan pertanian desa Alamendah mencapai 22 hektar dengan volume produksi sebanyak 70 ton per masa panen atau kurang lebih 630 ton per tahun.Lahan pertanian merupakan pusat kegiatan utama penggerak urat nadi perekonomian warga masyarakat Alamendah.Lahan pertanian pesawahan padi, di wilayah ini menjadi tanaman yang langka.Padi hanya ditanam untuk keperluan konsumsi. Nilai produktivitas padi berada jauh di bawah nilai produktivitas sayur-mayur dan buah-buahan.Lahan pesawahan dan ladang ditanami berbagai sayur mayur dan buah-buahan.

Mayoritas mata pencaharian penduduk adalah petani dengan jumlah 1.050 pemilik lahan sendiri atau penyewa lahan dan buruh tani sejumlah 5.942. Buruh tani adalah mereka yang mempunyai lahan sedikit atau tidak sama sekali. Mereka mengandalkan tenaga dan keahliannya. Petani pemilik lahan terdiri dari; petani yang memiliki lahan di atas satu hektar, petani pemilik lahan antara setengah hektar sampai satu hektar dan petani yang memiliki kurang dari setengah hektar.

Produk hasil pertanian unggulan adalah berbagai jenis sayur mayur dan stroberi. Stroberi adalah tanaman primadona mulai 
tahun 2000-an. Tidak sedikit yang menjadikan lahannya sebagai objek pariwisata alam, yaitu menjual buah stroberi dengan cara memetik sendiri.Produktivitas masyarakat Desa ini termasuk tinggi. Hal ini dapat dilihat dari tingkat daya beli masyarakat dan pola kehidupan masyarakat. Rumah-rumah sudah permanen.Setiap rumah mempunyai kendaraan bermotor, minimal roda dua.

Harga-harga komoditas sayur mayur tidak dipermainkan oleh tengkulak, seperti masa lima belas tahun ke belakang. Ikatan kelompok tani dan koperasi, menjadi sarana bagi saluran pemasaran, baik ke pasar tradisional, dan pasar modern. Koperasi yang berpengaruh adalah koperasi pondok pesantren Al-Ittifaq. Dengan pola kelompok melalu koperasi, harga-harga lebih stabil. Jika suatu jenis komoditas sayuran tidak sesuai dengan harapan, biasanya lebih disebabkan karena salah perhitungan. Kondisi ini dapat ditutup oleh jenis komoditas sayuran yang lain pada masa setelahnya (Data Observasi, Pebruari 2010).

Pertumbuhan ekonomi masyarakat ditopang juga oleh perkembangan usaha-usaha kecil atau industri rumah tangga yang mengolah buahstroberi dan buah-buah lain menjadi manisan, dodol dan lain-lain. Ada pula industri rumah tangga alat-alat dapur seperti centok, sendok, penggaruk dari kayu, batok kelapa.Ada pula yang menekuni perdagangan hasil komoditas sayur mayur dengan cara mengirim ke pasar Induk Jakarta, Caringin Bandung, dan pasar-pasar lain. Adanya lokasi pariwisata Situ Patengan dan Kawah Putih yang hanya berjarak 10-an km menjadi pasar hasilhasil industri rumahan.

Pada Pebruari 2011 Desa Alamendah ditetapkan oleh Bupati, sebagai urutan pertama di antara sepuluh desa wisata, dengan produk unggulan aneka makanan olahan stroberi, kerajinan tangan, pertanian dan perkebunan. Pemerintahan desa menitikberatkan agar masyarakat dapat bersikap responsif terhadap kondisi lingkungan dan dapat mendorong pemberdayaan, sehingga tercapai kesinambungan pembangunan di segala bidang. Penetapan ini tidak lepas dari pengaruh pengembangan agribisnis yang dilakukan oleh pesantren Al-Ittifaq bersama masyarakat. Pesantren dinilai berperan sentral dalam berbagai aspek kehidupan masyarakat (www.bandungkab.go.id). 
Dalam konteks budaya nusantara, wilayah desa Alamendah Rancabali termasuk masyarakat tatar Sunda yang dikenal sebagai masyarakat yang ramah, santun, dan tidak ambisius. Etnis Sunda atau 'urang Sunda' menduduki wilayah yang dikenal dengan sebutan Tatar Sunda, Pasundan, atau Bumi Parahyangan. Kata Sunda sendiri mempunyai arti bagus, baik, bersih, cemerlang atau segala sesuatu yang mengandung unsur kebaikan (Sutardi W., 2001). Orang Sunda memiliki etos dan watak kasundaan yaitu jalan menuju keutamaan hidup yaitu cageur (sehat), bageur (baik), bener(benar), singer (mawas diri), dan pinter (pandai, cerdas) (Fitri L, 2011).

Pada abad XV, dari aspek sosial ekonomi terdapat berbagai jenis pekerjaan yang memperlihatkan kemajuan bidang ekonomi. Jenis pekerjaan terdiri dari aparatur negara, cendikiawan/ rohaniawan, petani, seniman, perajin dan peternak.Posisi pedagang menempati profesi penting. Kerajaan Sunda memiliki enam buah pelabuhan, yaitu Banten, Pontang, Cigede, Tamgara, Kalapa dan Cimanuk (Mumuh MZ., tt.).

Kemajuan sosial ekonomi, menyebabkan Belanda memilih Banten pada tahun 1596 sebagai tempat pertama yang disinggahi. Dengan kekuatan VOC-nya tahun 1602 melakukan penaklukan wilayah tatar Sunda hingga tahun 1677 berada dalam kontrol Belanda. Tahun 1677 VOC menerapkan sistem eksploitasi di tatar Sunda yang dikenal Preanger Stelsel, yaitu sistem tanam kopi, dan pajak, kemudian tahun 1800 dirubah menjadi sistem tanam paksa (Cultur Stelsel) dengan tanaman wajib, kina, teh, dan karet.Sejarah panjang tatar Sunda demikian, mengindikasikan adanya sisa-sisa pengaruh penjajah dalam kehidupan masyarakat tatar Sunda.

Berdasar kekuatan sosial ekonomi, budaya dan kekuatan religiusitas, kabupaten Bandung secara formal menetapkan misi; terwujudnya masyarakat kabupaten Bandung yang Repeb Rapih Kertaraharja, melalui akselerasi pembangunan partisipatif yang berbasis religius, kultural dan berwawasan lingkungan, dengan berorientasi pada peningkatan kinerja pembangunan Desa. Kabupaten Bandung bertekad melaksanakan pembangunan dalam rangka mencapai kesejahteraan.

Sektor ekonomi pertanian merupakan sektor penyumbang ketiga terhadap Produk Domestik Regional Bruto (PDRB) kabupaten 
Bandung setelah industri pengolahan, perdagangan hotel dan restoran. Di bawah ini struktur ekonomi kabupaten Bandung berdasar sektor ekonomi.

$$
\text { Tabel } 1
$$

Struktur Ekonomi Kabupaten Bandung Tahun 2008 dan 2009

\begin{tabular}{clcc}
\hline No & \multicolumn{1}{c}{ Sektor } & 2008 & 2009 \\
\hline 1 & Industri Pengolahan & $60,80 \%$ & $60,00 \%$ \\
2 & Perdagangan, Hotel dan Restoran & $15,69 \%$ & $16,56 \%$ \\
3 & Pertanian & $7,13 \%$ & $7,36 \%$ \\
4 & Jasa-jasa & $5,06 \%$ & $5,05 \%$ \\
5 & Angkutan dan Komunikasi & $4,78 \%$ & $4,78 \%$ \\
6 & Keuangan, Sewa dan Jasa Perusahaan & $2,36 \%$ & $2,36 \%$ \\
7 & Bangunan & $1,69 \%$ & $1,70 \%$ \\
8 & LGA & $1,68 \%$ & $1,65 \%$ \\
9 & Pertambangan dan Galian & $1,22 \%$ & $1,28 \%$ \\
\hline
\end{tabular}

Sumber : Data Pusat Statistik Kab. Bandung tahun 2009

Sektor pertanian dalam tahun 2007-2009 mengalami peningkatan dalam laju pertumbuhan ekonominya, yakni 2,5\% tahun 2007, 3,97 \% tahun 2008 dan 5,31 \% pada tahun 2009 (BPS, 2009: 39). Kinerja sektor pertanian mengalami peningkatan yang signifikan. Laju pertumbuhannya meningkat 1.34 poin dari 3.97 persen tahun 2008 menjadi 5.31 persen tahun 2009. Hal ini sejalan dengan peningkatan di semua sub sektor pertanian (PDRB kab Bandung, 2009).

Peningkatan terbesar terjadi pada sub sektor peternakan dan sub sektor tanaman bahan makanan. Hal ini terkait dengan program peningkatan pembangunan dalam bidang pertanian di kabupaten Bandung, dan potensi pertanian yang besar sehingga menjadi salah satu daerah penyangga kebutuhan pangan di wilayah Jawa Barat. Di samping memiliki sentra produksi padi dan palawija, wilayah Bandung Selatan memiliki produksi sayuran unggulan dan buahbuahan. Pemanfaatan lahan dilakukan di wilayah pegunungan meliputi kawasan hutan lindung, hutan produksi, dan perkebunan. 
Filsafat Tri Tangtu Silih Asib Asab dan Asub

Filsafat tri tangtu silih asih asab dan asuh, telah mentradisi dalam kehidupan sosial, bahkan menjadi penopang bagi kemajuan perekonomian masyarakat. Filsafat tri tangtu telah menjadi perekat atau kohesi sosial dan mengakar dalam keseluruhan interaksi sosial ekonomi, agar saling menguntungkan. Secara psikologis, filsafat tri tangu silih telah menjadi semacam pedal gas pelancar tindakan individu dan kolektif bagi kemajuan bersama. Pada sisi lain, ia menjadi rem sosial bila tergelincir pada hal-hal yang menimbulkan kekurang harmonisan.

Berdasar hasil observasi dan pengujian data selama penelitian, ditemukan fakta bahwa pemberdayaan ekonomi masyarakat di desa Alamendah sangat dipengaruhi oleh keberadaan filsafat tri tangtu silih dan telah menjadi menjadi episentrum yang melahirkan konsekuensi berbagai komitmen. Komitmen amanah saling percaya, saling mengayomi dan memajukan serta komitmen bersaing dalam kebajikan. Posisi dan ekspresi filsafat tri tangtu silibdapat digambarkan sebagai berikut:

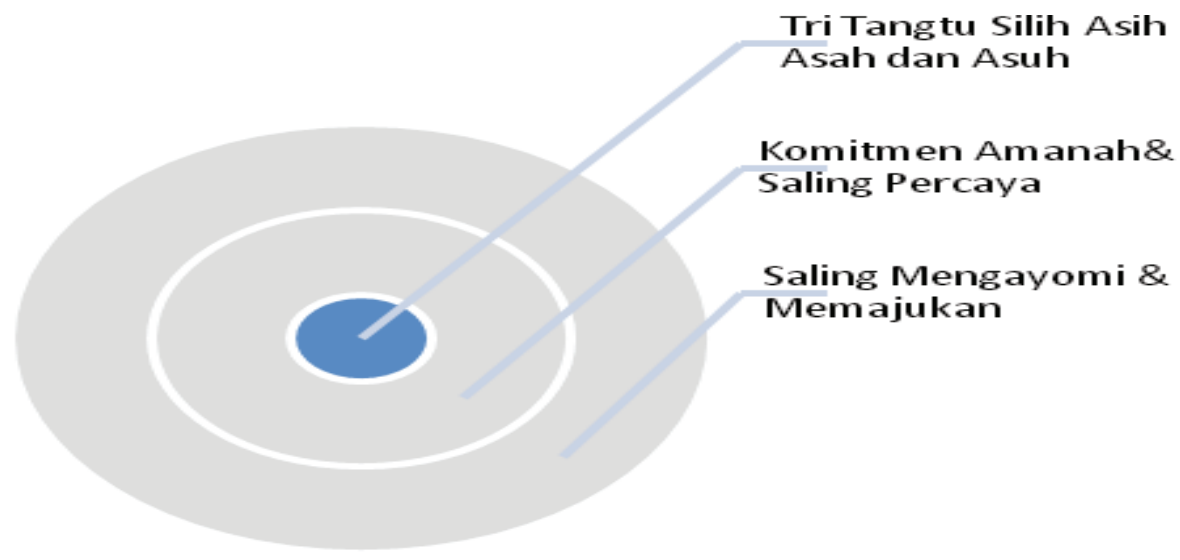

Sumber: Data terolah

Gambar 1

Konsekuensi Filsafat Tri Tangtu Silih pada sikap pelaku bisnis Gambar itu dapat dijelaskan sebagai berikut: 
1. Silih asih asah dan asuh

Pemberdayaan ekonomi di desa Alamendah melalui jaringan kelompok tani dapat berkembang dan mencapai kemajuan dengan filsafat tri tangtu silih sebagai episentrumnya. Telah terjadinya hubungan sosial yang erat dn berpengaruh nyata terhadap lahirnya berbagai komitmen sosial ekonomi. Tri tangtu silih, menjunjung tinggi relasi fungsional bagi kemajuan dalam berbisnis sekaligus meningkatkan kesejahteraan ekonomi.

2. Komitmen amanah dan saling percaya

Keseluruhan bisnis dikelola dan dikembangkan dengan landasan tri tangtu silih yang membuahkan komitmen amanah saling percaya mempercayai sebagai wujud optimal fungsi abdullah dan khalifatullah.

3. Komitmen saling mengayomi dan memajukan

Aktivitas pengelolaan dan pengembangan entitas bisnis tidak hanya bertujuan kemajuan pribadi, tetapi juga sesama.Filsafat tri tangtu silih melahirkan komitmen kerjasama kemitraan, saling mengayomi dan memajukan terutama di antara anggota kelompok tani.

Sedangkan dari tinjauan aspek fungsi, dimensi dan tujuannya, filsafat tri tangtu silih dapat dijelaskan sebagai berikut:

Tabel 2

Filsafat Tri Tangtu Silib: Fungsi Dimensi dan Tujuan

\begin{tabular}{llll}
\hline Elemen & \multicolumn{1}{c}{ Fungsi } & \multicolumn{1}{c}{ Dimensi } & \multicolumn{1}{c}{ Tujuan } \\
\hline Silih & - Pedoman prinsip & - Sosial ekonomi & - Kesadaran jati \\
Asih & interaksi & poltik dan budaya & diri (hamba dan \\
Silih & - Perekat sosial & - Lahiriyah & khalifah) \\
Asah & - Pendorong & - Batiniyah & - Kohesivitas sosial \\
dan & kemajuan & & ekonomi \\
Silih & & - Produktivitas \\
Asuh & & individu \\
& & - Kemajuan dan \\
& & kesejahteraan umat \\
\hline
\end{tabular}

Sumber: Data terolah

Keberadaan budaya Sunda dalam masyarakat desa Alamendah pada satu sisi dan sikap religiusitas masyarakatnya, telah saling 
menguatkan antara filsafat 'tri tangtu', tiga silib dengan ajaran ukhuwah dari ajaran Islam. Kolaborasi kekuatan ukhuwah dan kearifan lokal tri tangtu silih, yang pada hakikatnya berakar dari ajaran Islam, telah memuluskan dan memudahkan terwujudnya kekokohan jalinan kerjasama kemitraan dalam pengembangan bisnis. Transaksi-transaksi bisnis dan aksi-aksi pengabdian kepada umat dilandasi saling percaya (amanah), saling mengontrol dan mengayomi, terutama ketika kerugian menimpa anggota jaringan.

Filsafat tri tangtu silib dan ukhuwah, dapat membentuk kesadaran kolektif dalam kohesivitas ekonomi bisnis, mendorong keharusan berdaya saing, berorientasi pasar dan memuaskan pelanggan, keuntungan sepadan (material-immaterial) serta pengabdian bagi peningkatan kesejahteraan umat.Terbentuknya kohesivitas itu didukung pula oleh adanya kelembagaan aturan sosial masyarakat yang berujud pamali, dan parancah (suatu hal yang jika dilakukan akan berdampak negatif), yang diposisikan sebagai bagian dari larangan agama semacam makrub. Sedangkan parancah, semacam do'a-do'a dalam bahasa Sunda keseharian untuk menguatkan semangat atau menghindarkan dari hal-hal yang tidak diinginkan. Contoh sima aing sima maung, jiwaku berjiwa seperti keberanian harimau). Pamali dan parancah dapat diposisikan sebagai modal sosial kolektif (Kedi Suradisatra, 2008).

Silih asih silih asuh dan silih asah mengajarkan saling mengasuh dan mengasihi, saling berbagi pengetahuan dan pengalaman. Filosofi ini dipengaruhi oleh kondisi alam yang subur dan alami. Masyarakat akrab dengan lingkungan dan melestarikannya, menjadikan orang Sunda selalu dekat dengan Allah SWT dan sesama. Filsafat silih asih memperlihatkan karakter budaya religius yang khas sebagai konsekuensi pandangan hidup. Silih asih merupakan wujud hubungan interaksi sosial yang berpijak pada kasih sayang Allah SWT kepada makhluk, diimplementasikan dalam keseharian melalui cinta kasih kepada sesama. Silih asih memungkinkan kesiapan sikap untuk saling memberi dan menerima.

Semangat ketuhanan kemanusiaan dalam silih asih melahirkan nilai dan moralitas egaliter (persamaan derajat) dalam masyarakat. Masyarakat silih asih, saling menghormati dan tidak menganggap orang lain lebih rendah. Dari etos dan moralitas itu, mereka ber- 
potensi hidup teratur, dinamis dalam harmoni. Filosofi silih asah mendorong masyarakat mengembangkan diri, saling berbagi pengetahuan dan teknologi untuk kemajuan. Silih asah melahirkan etos progresif bagi tumbuhnya kemandirian dan kedisiplinan, tidak bergantung padaorang lain. Prinsipnya, budi akal lantaran ti papada jalma. Ulab adigung adiguna, agul ku payung butut. Sedangkan filosofi silih asuh mengharuskan sikap saling mengayomi, saling membina dan membantu yang kekurangan. Kepentingan kolektif atau pribadi diposisikan harus mendapat perhatian serius melalui saling kontrol, tegur sapa, dan saling menasehati.

Kekuatan filsafat tri tangtu silih menjadikan kehidupan masyarakat tata tentrem repeh rapih (tentram lahir batin dan teratur). Jeung dulur ulah pacogregan, (dengan saudara itu tidak diperkenankan ada perselisihan), kudu kawas dulur pet ku hinis, (memperlakukan orang lain harus seperti dengan saudara kandung), lain deungeun-deungeun, (sesama itu bukanlah orang lain).

Kudu sabilulungan gugur gunung, (harus sepenanggungan bergotong royong), sareundeuk saigel sabobot sapibanean, (saling mengingatkan bila orang lain atau tetangga melakukan tindakan yang merugikan masyarakat), nulung kanu butub, nalang kanu susah (memberi pertolongan terhadap yang membutuhkan, dan menjadi benteng atau penanggung jawab bagi orang yang terkena musibah). Filsafat tri tangtu silih bukan hanya terlihat jelas dalam relasi sosial tetapi pada relasi ekonomi dan bisnis. Mereka saling bertransaksi hasil panen, bibit tanaman, pupuk dengan mudah dan saling percaya. Bahkan saling mendukung permodalan secara mudah, tanpa syarat dengan motif saling memajukan.

Memuliakan dan mengutamakan pelanggan sudah menjadi keseharian pula yang mengarahkan pada terbangunya jaringan persaudaraan antara pihak-pihak yang terlibat dalam keseluruhan proses dan pasca bisnis. Dari konsekuensi filsafat tri tangtu, perilaku ekonomi bisnis yang dijalankan bernuasa distribusi sosial ekonomi. Hal ini seirama dengan arahan implementasi ekonomi bisnis Islam dalam produksi, konsumsi dan distribusi yaitu terwujudnya kemaslahatan. Keberhasilan yang dicapai dapat memberi nilai tambah bagi sesama. Keharusan zakat harta, zakat profesi dalam 
ekonomi Islam menunjukkan ketegasanadanya nuansa distribusi sosial ekonomi.

\section{Kelompok Tani dan Kopontren sebagai Motor Penggerak}

Gambaran kekuatan sistem nilai dalam masyarakat desa Alamendah di atas, tidak akan mewujud menjadi suatu keberhasilan pemberdayaan ekonomi tanpa adanya motor penggerak. Siapakah yang menjadi motor penggeraknya?Ditemukan fakta, motor penggerak pemberdayaan ekonomi adalah jaringan kelompok tani dan koperasi pondok pesantren yang telah mewujud menjai koorporasi bisnis.

Terdapat enam kelompok tani utama di bawah naungan kopontren Al-Ittifaq. Dalam sejarahnya kelompok tani dibentuk untuk pengelolaan sistem pola tanam, bergantian agar tidak terjadi over load hasil panen komoditas yang sama. Dalam perkembangannya, fungsi kelompok tani melebar ke aspek budi daya, pengolahan pasca panen, pemasaran bahkan permodalan. Dalam perkembangan itulah, kopontren difungsikan sebagai pengayom dan pelindung, terutama aspek pemasaran ke pasar-pasar modern super market.

Setiap kelompok tani mempunyai sejumlah kelompok tani yang dikembangkan secara berkesinambungan, sesuai kebutuhan di lapangan. Di bawah ini tabel jumlah anggota, luas lahan dan koordinator.

Tabel 3

Kelompok Tani, Jumlah, Lahan dan Koordinator

\begin{tabular}{lllll}
\hline No & Kelompok Tani & Anggota & Luas Lahan & \multicolumn{1}{c}{ Koordinator } \\
\hline 1 & Alif & 31 orang & $14 \mathrm{Ha}$ & KH Apep Syarifudin \\
2 & Jampang Endah & 35 orang & $22 \mathrm{Ha}$ & H Muhaimin \\
3 & Tunggal Endah & 32 orang & $20 \mathrm{Ha}$ & H Asep \\
4 & HMS & 29 orang & $20 \mathrm{Ha}$ & H Utang \\
5 & Mekar Tani & 27 orang & $8 \mathrm{Ha}$ & Wawan \\
6 & Tani Ulin & 23 orang & $6 \mathrm{Ha}$ & Hj. Netti \\
& Jumlah & 177 orang & $90 \mathrm{Ha}$ & \\
\hline
\end{tabular}

Sumber: Hasil wawancara diolah.

Jumlah anggota kelompok tani di atas, pada kenyatannya lebih banyak dari jumlah tersebut. Setiap kelompok tani yang 
sudah mapan telah mempunyai sub-sub kelompok tani yang baru. Kelompok tani yang baru didasarkan pada kebutuhan pembinaan pada anggota jaringan yang belum terwadahi oleh kelompok tani yang sudah ada. Kelompok tani HMS misalnya kini telah mempunyai binaan tiga sub kelompok tani. Demikian pula, Mekar Tani, Jampang Kulon dan lain-lain.

Keberadaan kelompok tani dalam naungan kopontrenberfungsi pula sebagai penggerak pemberdayaan ekonomi masyarakat. Melalui kelompok tani, para petani atau pebisnis dapat mengatur secara baik tentang pola tanam, kualitas produksi hasil panen, peningkatan kapasitas individu dan kuantitas produk. Usaha-usaha mereka menjadi semakin terorganisir sehingga menguatkan daya tawar terutama dalam hal harga. Mereka tidak akan dimainkan oleh tengkulak. Para anggota diberdayakan dengan pelatihan dan konsultasi pertanian, penggunaan teknologi, pembibitan, pengolahan, pupuk dan obat, pengemasan, grading, dan sortasi dan lain-lain.

Sebagai koordinator, kopontren berfungsi menyelenggarakan penyuluhan dan pelatihan tentang penerapan teknologi tepat guna. Hal ini dilakukan agar setiap proses, baik pada proses produksi, proses panen, dan pasca panen serta informasi terkait antara produk dengan permintaan pasar dapat terjalin lebih baik dan berkelanjutan. Kopontren juga difungsikan semacam perusahaan inti, yang berfungsi bukan hanya membina, membimbing, mengembangkan anggotanya, tetapi juga sampai pada pertanggung-jawaban menjaga kesinambungan produksi dan mengayomi anggota yang terkena kerugian.

Dalam prosesnya, secara bertahap dan berkesinambungan, proses pemberdayaan ekonomi masyarakat di desa Alamendah dapat digambarkan sebagai berikut:

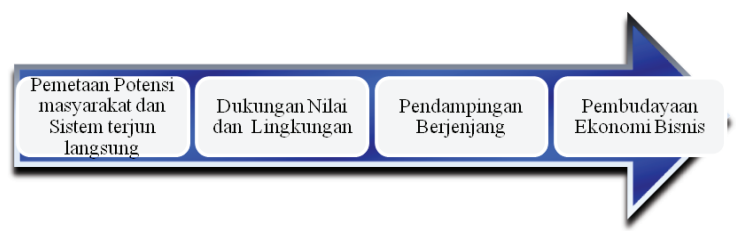

Sumber: Data terolah

Gambar 2

Proses Pemberdayaan Ekonomi masyarakat 
Pola pemberdayaan ekonomi, pertama-tama dilakukan pemetaan potensi masyarakat dan mempraktekkannya dengan sistem terjun langsung. Dalam proses itu, secara berjenjang para petani yang baru bergabung didampingi oleh kelompok-kelompok tani pembina dalam aura pembudayaan ekonomi bisnis dengan dukungan sistem nilai dan lingkungan yang baik. Secara bertahap, terstruktur dan berkesinambungan dilakukan pembudayaan ekonomi bisnis yang terpadu dengan dukungan jaringan kerjasama kemitraan antar kelompok tani yang solid.

Kopontren menerapkan sistem manajemen sistem sel. Kopontren sebagai inti dan kelompok tani plasmanya. Kelompok tani yang sudah mapan dapat menjadi sub inti dan membuat plasma dengan melakukan pemekaran kelompok tani binaannya menjadi plasma baru dan seterusnya. Kopontren melakukan desentralissi dan pembagian tugas agar pengelolaan bisnis di antara kelompok tani. Sistem operasi bisnis, sistem produksi dan sistem pemasaran telah terorganisir dengan baik.Dengan sistem itu, maka generasi selanjutnya tidak akan kesulitan dalam meneruskan kepemimpinan, termasuk dalam pengembangan bisnis.

Jalinan kerja sama kemitraan usaha di antara mereka dapat disebut bersifat "two in one business partnership". Kopontren bekerjasama dengan kelompok-kelompok tani dalam rangka pemenuhan komoditas pertanian. Di pihak lain melakukan kemitraan dengan supermarket, byper market atau pasar swalayan dalam pemasaran hasilnya.Kopontren, telah menjalin kontrak kerja jangka panjang dengan perusahaan mitra yaitu Hero (Jakarta), serta supermaket (pasar swalayan) di Bandung yaitu Merlin, Yogya Departemen Store, Ramayana dan Matahari. Pesanan berbagai sayuran dan buah untuk pasar swalayan setiap harinya tidak kurang dari 9 ton.

Sebagai perusahaan inti kopontren menampung dan membeli hasil pertanian dari kelompok tani, memberikan bimbingan teknis, sarana produksi, bantuan permodalan, penetapan pola tanam serta penerapan teknologi tepat guna kepada kelompok tani binaannya. Sedangkan kelompok tani sebagai mitra mempunyai kewajiban menjual sebagian produknya melalui kopontren pada saat dibutuhkan dengan harga yang disepakati. Mematuhi standarisasi dan pola 
tanam serta melaporkan berbagai permasalahan yang terjadi untuk dicarikan jalan keluarnya.

Kopontren melakukan olah produksi dan pemanfaatan hasil. Olah produksi meliputi proses penanaman, pemeliharaan, panen, pergudangan,hingga pemasaran. Sedangkan pemanfaatan hasil adalah proses pengelolaan asset anggota koperasi (pasca penjualan) untuk peningkatan kesejahteraan anggota dan masyarakat. Pemanfaatan hasil adalah memanage karunia Allah. Dalam prakteknya, kopontren dapat diilustrasikan sebagai play maker dalam permainan sepak bola, yaitu penyeimbang usaha, pemberi umpan, pendorong serangan (marketing) dan lain-lain. Kopontren dapat melakukan penguatan fungsi pemasaran; mempertahankan kongsi yang ada dan mencari memperluas pasar baru.

Untuk stabilisasi dan penguatan jaringan, telah dibentuk pula balai mandiri terpadu, pusat inkubator agribisnis, usaha bengkel, peternakan dan lain-lain. Pengembangan kelembagaan ini seiring program pemerintah melalui Lembaga Mandiri yang Mengakar di Masyarakat (LM3) yang secara fungsional saling mendukung di antara elemen di dalamnya meliputi kopontren, kelompok-kelompok tani, P4S (Pola Pusat Pelatihan Pertanian dan Pedesaan Swadaya) dandewan kesejahteraan masjid (DKM). Jaringan kerjasama kemiteraan di atas secara massal diperkuat oleh silaturahmi terpola yang berkesinambungan melalui berbagai perayaan momen-momen hari besar Islam, seperti maulid Nabi, Isra Mi'raj dan lain-lain yang diselenggarakan secara bersama-sama.

Paparan di atas, memperlihatkan bagaimana masyarakat desa Alamendah telah mengoptimalkan berbagai kekuatan fungsi dan modal sosial, terutama filsafat tri tangtu bagi pemberdayaan ekonomi masyarakat. Dengan modal sosial tri tangtu yang sudah mentradisi maka, ketika terjadi perselisihan di antara anggota jaringan, sangat mudah diselesaikan. Mereka dapat mudah mengembalikan masalah pada duduk perkaranya.

Persaudaran lebih diutamakan dan harus dijaga.Bila terjadi kekurangan atau keterlambatan pembayaran, jika masih dalam kewajaran maka, mudah dipahami. Persaingan dalam dunia bisnis 
tidak dapat dihindari.Ketika kedua belah pihak memahami logika dan konsekuensi bisnis, menjadi mudah menyelesaikannya. Kejadian rebutan pelanggan atau salah paham kerap terjadi, namun karena mempunyai saluran penyelesaian yang baik melalui musyawarah dalam kelompok tani, masalah besar-pun menjadi mudah diselesaikan.

\section{Kesimpulan}

Pemberdayaan ekonomi melalui optimalisasi sistem nilai (kearifan lokal) yang dimiliki oleh suatu masyarakat, secara signifikan dapat mendorong percepatan keberhasilan pemberdayaan tersebut. Filsafat tri tangtu silib terbukti menjadi episentrum dalam pemberdayaan ekonomi masyarakat di desa Alamendah Rancabali kabupaten Bandung. Sistem nilai dalam suatu masyarakat merupakan modal sosial yang dapat berdaya guna untuk berbagai kepentingan bagi pencapaian kemajuan masyarakat.

Dalam implementasinya, diperlukan motor penggerak dan kesinambungan jaringan yang terkait langsung dengan potensi ekonomi yang dimiliki masyarakat. Motor penggerak berfungsi, bukan hanya sebagai inisiator, melainkan sebagai play makeryang totalitas meliputi fungsi pendampingan, pengayom, dan penjaga stabilitas jaringan kemiteraan.

Implementasi modal sosial kearifan lokal, hubungan fungsional optimal jaringan kelompok sebagai perusahaan plasma dan koperasi sebagai perusahaan intitelah menjadikan pemberdayaan ekonomi dapat berhasil dicapai dalam waktu yang tidak lama. Di wilayah lain dengan demikian, sangat mungkin dilakukan pemberdayaan ekonomi masyarakat dengan pola dasar serupa, dengan mengoptimalisasikan sistem nilai kearifan lokal dan pelembagaan sistem jaringan sebagai motor penggeraknya. Hanya saja, yang patut menjadi perhatian adalah potensi ekonomi, pemilihan sistem nilai yang dimiliki, serta pembangunan jejaring guna mendialogkan secara inten antara sistem nilai lokalitas dan potensi ekonomi yang dimiliki. 


\section{Daftar Pustaka}

Abdullah, Irwan.1994.The Muslim Businesman of Jatinom, Religious reform and economic modernization in a central Javanese town, Amsterdam:Universiteit Van Amsterdam.

Anonim. 2011. Kebijakan Bidang Sosial Budaya, Bappeda Provinsi Jawa Barat.

Castle, Lance. 1982. Tingkah Laku Agama, Politik dan Ekonomi di Jawa: Industri Rokok Kudus,Jakarta: Sinar Harapan.

Creswell, John W. 1998. Qualitative Inquiry and Research Desain, Califormnia: Sage Publications.

Knop, Bogdan Robert C Biklen Sari,1992. Qualitative for Education an Introduction to Theory Methods, Boston London SydneyToronto: Allyn and Bacon.

Kurnia, Ganjar. 2004. "Nuansa Islam dalam Kesenian Sunda".Harian umum Pikiran Rakyat, 23 Oktober.

Muhsin Z,Mumuh,tt., Kondisi Sosial Ekonomi Masyarakat Tatar Sunda dari Masa Tarumanagara s.d. Masa Kolonial Belanda, makalah diskusi Dosen Fakultas Sastera Universitas Padjajaran, tidak diterbitkan.

PDRB Semesteran Biro Pusat Statistik Kabupaten Bandung 2009.

Panadji, Tri , 2006. "Penguatan Modal Sosial untuk Pemberdayaan Masyarakat Pedesaan dalam Pengelolaan Agroekosistem Lahan Kering, Jurnal Agroekonomi, Volume 24 No 2 Oktober.

Suradisatra, Kedi. 2008. "Strategi Pemberdayaan Kelembagaan Petani," Forum Penelitian Agro Ekonomi, volume 26 no 2, Desember.

Syafe'i, Agus Ahmad. 2010. "Menatap Wajah Islam dari Jendela Sunda", makalah Annual Conference on Islamic Studies (ACIS ke 10) di Banjarmasin, 1 - 4 November.

Syahza, Alhahdi. 2003. "Rancangan Model Pemberdayaan Masyarakat Pedesaan Berbasis Agribisnis di Daerah Riau, Jurnal Pembangunan Pedesaan, Universitas Jenderal Soedirman, vol 3 no 2.

Syahyuti. 2008. "Peran Modal Sosial dalam Perdagangan Hasil Pertanian", Forum Agro Ekonomi, Vgatolume 26 No 1 Juli. 